\title{
Prevalensi Kuman Multi Drug Resistance (MDR) di Laboratorium Mikrobiologi RSUP Dr. M. Djamil Padang Periode Januari 2010 - Desember 2012
}

Novilla Rezka Sjahjadi, Roslaili Rasyid, Erlina Rustam, Lily Restusari

\begin{abstract}
Abstrak
Kuman Multi Drug Resistance (MDR) menyebabkan semakin sulit dalam memilih antibiotika untuk pasien yang mengalami infeksi. Akibat sulitnya pemilihan antibiotika, bisa terjadi perpanjangan masa rawat di Rumah Sakit dan menyebabkan kemunduran dalam dunia medis, sosial dan ekonomi secara tidak terduga. Telah dilakukan penelitian deskriptif-retrospektif dengan mengambil data kuman penyebab infeksi yang mengalami Multi Drug Resistance (MDR) di RSUP Dr. M. Djamil Padang periode Januari 2010 - Desember 2012 untuk mengetahui kuman Multi Drug Resistance (MDR) dan prevalensi kuman Multi Drug Resistance (MDR) di RSUP Dr. M. Djamil Padang periode Januari 2010 - Desember 2012. Hasil Penelitian menunjukkan dari 6.387 jumlah spesimen yang diambil dan dilakukan uji sensitifitas, ditemukan 3.689 kuman yang telah mengalami Multi Drug Resistance (MDR) diantaranya kuman Klebsiella sp, Staphylococcus aureus, Enterobacter sp, E.coli sp, Pseudomonas sp, dan Proteus sp. Dari 3.689 kuman yang mengalami Multi Drug Resistance (MDR) di RSUP Dr. M. Djamil Padang, peningkatan resistensi paling tinggi ditemukan pada tahun 2010 dan meningkat kembali ditahun 2012. Hasil ini menunjukkan bahwa, kasus Multi Drug Resistance (MDR) sudah ditemukan pada hasil kuman yang dikultur di Laboratorium Mikrobiologi RSUP Dr. M. Djamil Padang dan kasus tertinggi ditemukan ditahun 2010 (62\%), kemudian menurun ditahun 2011 (55\%) dan kembali meningkat ditahun 2012 (58\%).
\end{abstract}

Kata kunci: kuman multi drug resistance, prevalensi, kuman

\begin{abstract}
Multi Drug Resistance (MDR) bacteria, makes harder to choose the right antibiotics to use for the treatment and can cause the longer of hospitality days and the sudden decrease of medic, social and economics. It had been conducted a descriptive-retrospective study by taking the data of bacteria that cause infections experienced Multi Drug Resistance (MDR) in RSUP Dr. M.Djamil Padang from January 2010 - December 2012 to find out the Multi Drug Resistance (MDR) bacteria in RSUP Dr. M. Djamil Padang from January 2010 - December 2012. The result from the research from 6.387 study that shows the number of specimens taken and get sensitivity test, found 3.689 bacterias that have experienced the Multi Drug Resistance (MDR) including Klebsiella sp, Staphylococcus aureus, Enterobacter $s p$, E.coli sp, Pseudomonas sp, dan Proteus sp. The highest resistance from 3.689 Multi Drug Resistance (MDR) bacteria was in 2010 and increased again in 2012. These result indicate that, Multi Drug Resistance (MDR) case has been found in bacteria from specimen in Laboratory of Microbiology RSUP Dr. M. Djamil Padang and the highest was discovered in 2010 (62\%), than decreased in 2011 (55\%) and increased again in 2012 (58\%).
\end{abstract}

Keywords:Multi Drug Resistance bacteria, prevalention, bacteria

Affiliasi penulis : Fakultas Kedokteran Universitas Andalas Korespondensi :Novilla Rezka Sjahjadi, email:

novillarezkasjahjadi@gmail.com, Telp: 083186999293

\section{PENDAHULUAN}

Munculnya bakteri yang resisten terhadap beberapa antibiotika tertentu memberikan perhatian 
yang cukup besar pada instansi kesehatan di seluruh dunia. Hal ini menunjukkan bahwa antibiotika tidak bekerja optimal dan penyakit yang awalnya telah membaik, dapat dialami kembali dengan prognosis yang lebih buruk. ${ }^{1}$

Infeksi yang disebabkan oleh bakteri yang resisten terhadap antibiotika dapat meningkatkan morbiditas secara signifikan, perpanjangan masa rawat, dan peningkatan biaya kesehatan dibandingkan dengan infeksi yang disebabkan oleh bakteri yang masih rentan atau sensitif terhadap antibiotika. ${ }^{1}$

Berdasarkan hasil penelitian Lestari pada tahun 2010 di RS Dr. M. Djamil Padang didapatkan bakteri yang sering menginfeksi pasien di bangsal Penyakit Dalam RS M. Djamil Padang adalah Klebsiella spp 29,27\%, Proteus spp 21,95\%, Pseudomonas aureginosa $7,32 \%$ dan E. Coli $4,88 \%$. Antibiotika yang masih sensitif terhadap bakteri tersebut yaitu sefotaksim 10,18\%, seftazidim $10,18 \%$, meropenem 10,18\%, dan siprofloksasin 7,78\%. Ini menunjukkan bahwa angka kejadian resistensi antibiotika di kota Padang cukup tinggi. ${ }^{2}$

Konsekuensi dari resistensi antibiotika bukan hanya terlihat pada kehidupan pasien tapi juga bisa berdampak pada sistem pelayanan kesehatan dan kehidupan sosial seluruh dunia. Jika kasus resistensi antibiotik ini tidak ditangani serius, dalam beberapa tahun kedepan bisa saja terjadi kemunduran dalam dunia medis, sosial dan ekonomi secara tidak terduga. $^{3}$

\section{METODE}

Penelitian dilakukan dalam bentuk deskriptif retrospektif, yaitu dengan melakukan pengumpulan dari data yang telah ada dan di analisis kuman yang mengalami Multi Drug Resistance (MDR) di Laboratorium Mikrobiologi Rumah Sakit Dr. M. Djamil Padang dan antibiotika yang mengalami resistensi terhadap kuman MDR di lingkungan Rumah Sakit Dr. M. Djamil Padang.

Populasi dari penelitian adalah seluruh data kuman penyebab infeksi yang terdapat di Laboratorium Mikrobiologi Rumah Sakit Dr. M. Djamil Padang periode Januari 2010-Desember 2012. Sampel dari penelitian adalah data kuman penyebab infeksi yang terdapat di Laboratorium Mikrobiologi
Rumah Sakit Dr. M.Djamil Padang periode Januari 2010 - Desember 2012.

Langkah-langkah pengolahan data yang dilakukan adalah data kuman MDR dimasukkan dalam bentuk tabel kemudian dilakukan penghitungan untuk mencari persentase yang mengalami MDR dalam 1 tahun, kemudian data dimasukkan dalam bentuk grafik. Data yang dijadikan dalam bentuk grafik hanya yang jumlah kasusnya ditemukan 30 pertahunnya.

\section{HASIL}

Berdasarkan penelitian yang dilakukan, didapatkan enam kuman yang termasuk dalam kuman MDR, yaitu Klebsiella sp, Staphylococcus aureus, Enterobacter sp, E.coli sp, Proteus sp, danPseudomonas sp.

Tabel 1. Prevalensi Kuman MDR pada Laboratorium Mikrobiologi RSUP Dr. M.Djamil Padang pada Januari 2010 - Desember 2012

\begin{tabular}{|c|c|c|c|c|c|c|c|c|c|}
\hline \multirow{2}{*}{$\begin{array}{c}\text { Kuman Multi } \\
\text { Drug }\end{array}$} & \multicolumn{3}{|c|}{2010} & \multicolumn{3}{|c|}{2011} & \multicolumn{3}{|c|}{2012} \\
\hline & Non- & MDR & (\%) & non- & MDR & $\%$ & Non- & MDR & $\%$ \\
\hline $\begin{array}{c}\text { Resistance } \\
\text { (MDR) }\end{array}$ & MDR & & MDR & MDR & & MDR & MDR & & MDR \\
\hline \multirow[t]{2}{*}{ Klebsiella sp } & 378 & 555 & 59 & 756 & 859 & 53 & 460 & 57 & 55 \\
\hline & & & & & & & & 0 & \\
\hline Staphylococcu & 43 & 70 & 62 & 207 & 241 & 54 & 149 & 18 & 55 \\
\hline$s$ aureus & & & & & & & & 2 & \\
\hline Enterobacter & 69 & 93 & 57 & 35 & 39 & 53 & 1 & 2 & 67 \\
\hline \multicolumn{10}{|l|}{$s p$} \\
\hline E.colisp & 74 & 95 & 56 & 85 & 102 & 55 & 18 & 17 & 49 \\
\hline \multirow[t]{2}{*}{ Proteus $s p$} & 12 & 85 & 88 & 115 & 184 & 62 & 92 & 19 & 67 \\
\hline & & & & & & & & 0 & \\
\hline Pseudomonas & 10 & 70 & 88 & 100 & 155 & 61 & 94 & 18 & 66 \\
\hline$s p$ & & & & & & & & 0 & \\
\hline \multirow[t]{2}{*}{ Total } & 586 & 968 & 62 & 1298 & 1580 & 55 & 814 & 11 & 58 \\
\hline & & & & & & & & 41 & \\
\hline
\end{tabular}

Pada tabel 1 terlihat kejadian MDR tertinggi terjadi pada tahun 2010. Pada tahun 2011, terjadi penurunan kasus MDR pada tiap kuman yang ditemukan biakannya pada Laboratorium Mikrobiologi Rumah Sakit Dr. M. Djamil Padang dan ditahun 2012 peningkatan kasus MDR meningkat kembali.

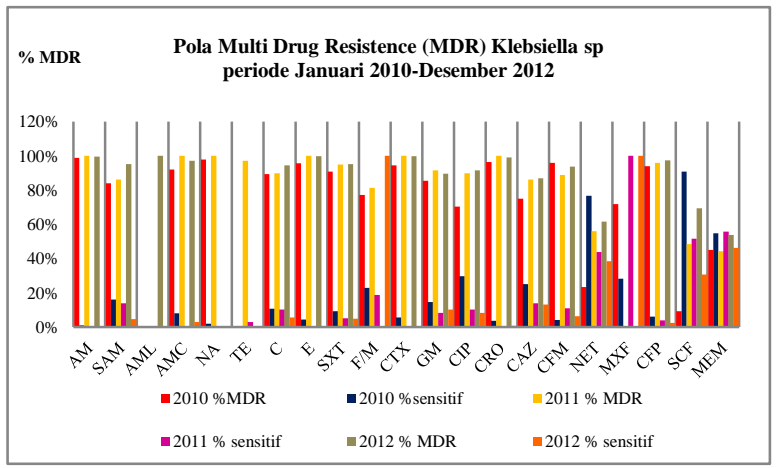


Grafik 1. Pola MDR Klebsiella sp Periode Januari 2010 Desember 2012

Pada grafik 1, terlihat Kuman Klebsiella $s p$ yang mengalami Multi Drug Resistence (MDR), di tahun 2010, resistensi tertinggi diperlihatkan terhadap antibiotika ampisilin, dan sensitifitas tertinggi diperlihatkan terhadap antibiotika kombinasi sulbaktam dan sefoperazon.

Pada tahun 2011, resistensi tertinggi diperlihatkan terhadap antibiotika ampisilin,sedangkan sensitifitas tertinggi terhadap antibiotika meropenem. Tahun 2012, resistensi tertinggi kuman terhadap antibiotika ampisilin, kombinasi ampisilin dan sulbaktam, serta eritromisin, sedangkan sensitifitas tertinggi terhadap antibiotika meropenem.

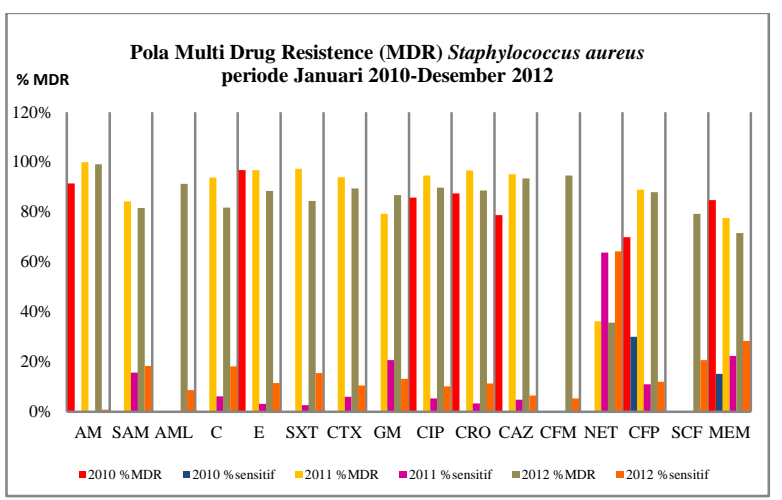

Grafik 2. Pola MDR Staphylococcus aureus periode Januari 2010-Desember 2012

Pada grafik 2, terlihat kuman Staphylococcus aureus yang mengalami Multi Drug Resistance (MDR), di tahun 2010 resistensi tertinggi diperlihatkan terhadap antibiotika Eritromisin dan sensitifitas tertinggi diperlihatkan terhadap antibiotika netilmisin. Pada tahun 2011, resistensi tertinggi kuman terjadi pada antibiotika ampisilin sedangkan sensitifitas tertinggi pada antibiotika netilmisin. Pada tahun 2012, resistensi tertinggi terhadap antibiotika ampisilin dan sensitifitas tertinggi pada antibiotika netilmisin.

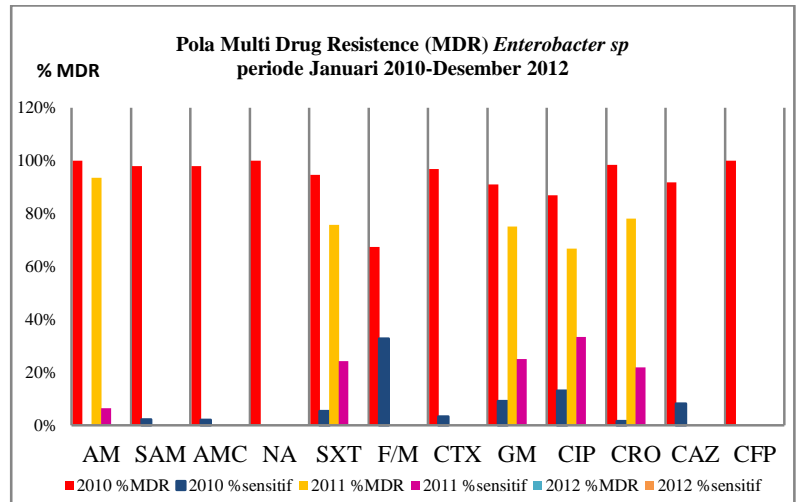

Grafik 3. Pola MDR Enterobacter sp Periode Januari 2010-Desember 2012

Pada grafik 3, terlihat kuman Enterobacter sp yang mengalami Multi Drug Resistence (MDR), resistensi tertinggi terhadap antibiotika ampisilin dan asam nalidiksat dan sensitifitas tertinggi terhadap antibiotika meropenem di tahun 2010. Pada tahun 2011, resistensi tertinggi kuman Enterobacter $s p$ terlihat pada ampisilin dan sensitifitas tertinggi terhadap antibiotika gentamisin.

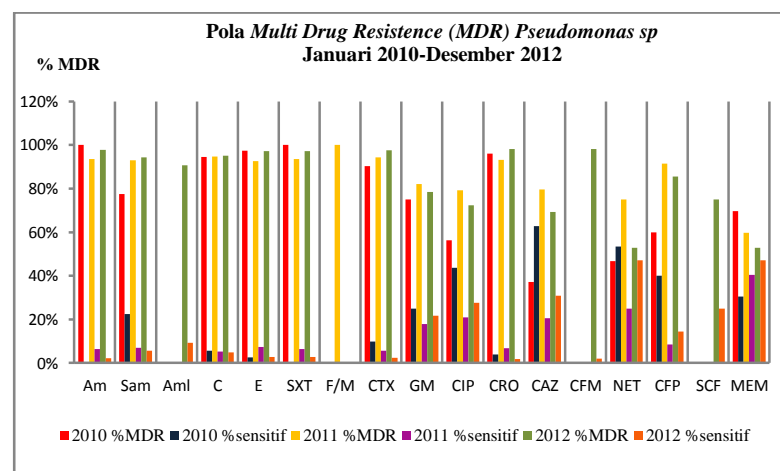

Grafik 4. Pola MDR Pseudomonas $s p$ periode Januari 2010-Desember 2012

Pada grafik 4, terlihat kuman Pseudomonas sp ditahun 2010 mengalami resistensi tertinggi terhadap antibiotika ampisilin dan seftriakson, sedangkan sensitifitas tertinggi terhadap antibiotika seftazidim.

Tahun 2011 didapatkan resistensi 
Pseudomonas $s p$ tertinggi terhadap antibiotika nitrofurantoin dan sensitifitas tertinggi pada antibiotika meropenem. Pada tahun 2012, resistensi tertinggi terjadi pada antibiotika ampisilin, sefotaksim, seftriakson, dan sefiksim, sedangkan sensitifitas tertinggi pada antibiotika netilmisin.

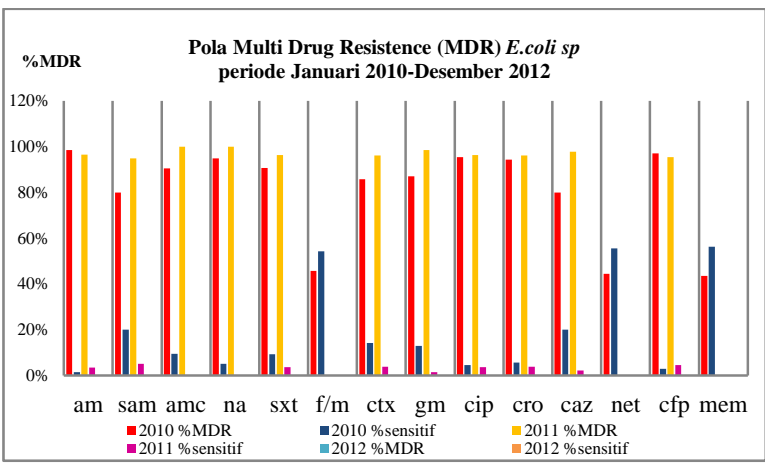

Grafik 5. Pola MDR E.coli sp Periode Januari 2010Desember 2012

Grafik 5 memperlihatkan kuman E.coli $s p$ yang mengalami MDR di tahun 2010 angka resistensi tertinggi terhadap antibiotika ampisilin sedangkan sensitifitas tertinggi terhadap antibiotika netilmisin dan meropenem.

Tahun 2011 terlihat resistensi tertinggi kuman E.coli $s p$ terhadap antibiotika kombinasi amoksilin dan klavulanat dan asam nalidiksat gentamisin dan sefazidim, sedangkan sensitifitas tertinggi terhadap antibiotika tidak ada yang melebihi $10 \%$.

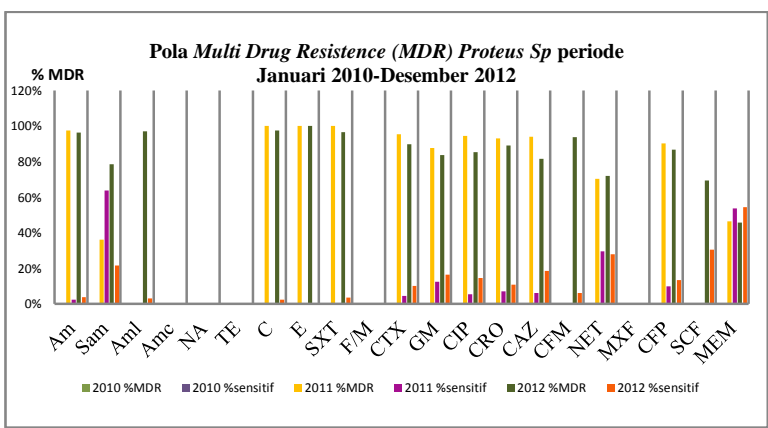

Grafik 6. Pola MDR Proteus sp Periode Januari 2010Desember 2012

Grafik 6 menggambarkan kuman Proteus mirabilis yang mengalami MDR di tahun 2011 angka resistensi tertinggi terhadap antibiotika kloramfenikol, eritromisin dan kotrimoksazol sedangkan sensitifitas tertinggi terhadap antibiotika kombinasi ampisilin dan sulbaktam.
Pada tahun 2012, angka resistensi tertinggi kuman terhadap antibiotika eritromisin dan sensitifitas tertinggi terhadap antibiotika meropenem.

\section{PEMBAHASAN}

Sejumlah 6.387 spesimen yang diambil dari berbagai macam infeksi pasien yang dirawat di RSUP Dr. M. Djamil Padang periode Januari 2010 Desember 2012 dan dilakukan uji kultur dan sensitifitasnya di Laboratorium Mikrobiologi, ditemukan 3.689 kuman yang telah mengalami MDR. Adanya kasus MDR yang kasusnya mencapai hampir $60 \%$ ini, menyebabkan sulitnya menentukan antibiotika yang akan digunakan untuk terapi infeksi pasien. Munculnya kasus MDRini, dapat disebabkan oleh peresepan antibiotika yang kurang tepat atau tidak sesuai dengan kuman penyebab dan penggunaan dari antibiotika yang tidak rasional. ${ }^{4}$

Hasil penelitian ini mendapatkan enam jenis kuman yang merupakan kuman MDR di Laboratorium RSUP Dr. M. Djamil Padang, diantaranya Klebsiella sp, Staphylococcus aureus, Enterobacter sp, Pseudomonas sp, E.coli sp, dan Proteus sp. Keenam kuman tersebut adalah kuman yang mengalami resistensi pada lebih dari empat golongan antibiotika yang berbeda golongan.

Antibiotika ampisilin di tahun 2010 telah mengalami resistensi $99 \%$ dan meningkat menjadi 100\% di tahun 2011 dan 2012. Ini menunjukkan ampisilin tidak dapat lagi digunakan untuk terapi infeksi Klebsiella sp. Pada antibiotika Amoksilin, terjadi peningkatan yang cukup tinggi, di tahun 2010, hanya $68 \%$ yang mengalami resistensi, namun, di tahun 2011 dan 2012, telah terjadi peningkatan menjadi $100 \%$. Ini artinya amoksilin tidak efektif lagi untuk pengobatan infeksi Klebsiella sp.

Berdasarkan penelitian Refdanita pada tahun 2010 yang dilakukan di Ruang Rawat Intensif RS Fatmawati Jakarta juga ditemukan hal yang sama dengan yang didapatkan dari penelitian di RS Dr. M. Djamil Padang, yaitu untuk antibiotika ampisilin resistensi mencapai $98 \%$ dan antibiotika amoksilin mencapai $100 \%{ }^{5}$

Pada kuman Staphylococcus aureus juga terjadi hal yang sama, ditahun 2010, resistensi pada ampisilin ditemukan 91\% kasus, kemudian meningkat 
menjadi 100\% ditahun 2011 dan 99\% ditahun 2012. Pada antibiotika amoksisilin, hanya bisa dilihat pada tahun 2012, yaitu sekitar $91 \%$ mengalami resistensi. Antibiotika kotrimoksazol pada tahun 2011 ditemukan 97\% kasus resistensi Staphylococcus aureus dan mengalami penurunan ditahun 2012 menjadi 85\%.

Pada kuman Pseudomonas sp, kasus resistensi tertinggi ditemukan pada antibiotika ampisilin, yaitu 100\% ditahun 2010, kemudian menurun menjadi 94\% ditahun 2011, dan meningkat menjadi 98\% ditahun 2012, sedangkan pada antibiotika amoksisilin, ditemukan 91\% kasus pada tahun 2012. Pada antibiotika kotrimoksazol, kuman Pseudomonas sp mengalami resistensi $100 \%$ ditahun 2010, kemudian menurun menjadi 94\% ditahun 2011 dan 97\% ditahun 2012.

Kasus resistensi untuk kuman ini, cukup tinggi di RSUP Dr. M.Djamil Padang, dilihat dari tahun 2010, ditemukan 98\% kasus resistensi terhadap antibioika ampisilin, 96\% ditahun 2011 dan meningkat menjadi $100 \%$ ditahun 2012. Antibiotika lini ketiga meropenem, ditahun 2010 ditemukan 44\% kasus yang mengalami resistensi, namun ditahun 2011 dan 2012, tidak dapat dilihat persentase kasusnya dikarenakan kasus yang ditemukan tidak mencukupi 30 pertahunnya.

Pada kuman Proteus sp, pada tahun 2011 resistensi terhadap ampisilin pada kuman MDR ditemukan $98 \%$ dan menurun menjadi $96 \%$ ditahun 2012. Antibiotika amoksilin, ditemukan $97 \%$ ditahun 2012, namun ditahun 2010 dan 2011 tidak dapat dilaporkan dikarenakan kasus yang ditemukan tidak mencukupi 30 pada satu tahun. Pada antibiotika kotrimoksazol hanya bisa dilaporkan pada tahun 2011 dan 2012, yaitu ditemukan 100\% ditahun 2011 dan menurun menjadi 96\% ditahun 2012. Antibiotika kloramfenikol yang merupakan antibiotika yang termasuk broad spectrum juga ditemukan resistensi 100\% ditahun 2011 dan menurun menjadi 97\% ditahun 2012. Antibiotika lini ketiga meropenem, ditemukan 46\% kasus resistensi ditahun 2011 dan menetap ditahun 2012 pada kuman Proteus sp. kuman yang mengalami Multi Drug Resistence (MDR) di Laboratorium Mikrobiologi RSUP Dr. M. Djamil Padang sudah mengalami resistensi terhadap antibiotika yang paling sering dan paling banyak digunakan di layanan primer kesehatan (Puskesmas), yaitu amoksisilin, ampisilin, tetrasiklin dan kotrimoksazol, selain itu, pada antibiotika lini ketiga yaitu meropenem, sudah terlihat adanya peningkatan kasus resistensi terutama pada kuman Staphylococcus aureus ditahun 2010, yaitu 85\%. Hendaknya penggunaan antibiotika ini mulai dibatasi dan mulailah mengobati infeksi kuman dengan menggunakan antibiotika yang sesuai dengan kuman penyebab dan gunakanlah lini pertama terlebih dahulu.

\section{DAFTAR PUSTAKA}

1. Mather AE, Matthews L, Mellor DJ (editor). An ecological approach to assessing the epidemiology of antimicrobial resistance in animal and human populations. 2011 (diunduh 20 November 2012). Tersedia dari: URL: HYPERLINK http://www.fmddisconvac.net

2. Lestari W, Almahdy A, Zubir N, Darwin D. Studi penggunaan antibiotik berdasarkan sistem ATC/DDD dan kriteria Gyysens di bangsal penyakit dalam RSUP Dr. M. Djamil Padang. 2011 (diunduh 6 April 2013). Tersedia dari: URL: HYPERLINKhttp://pasca.unand.ac.id/id/wpcontent /uploads/2011/09/artikel-publikasi.pdf

3. React fact. Burden of antibiotic resistance. 2011 (diunduh 22 November 2012). Tersedia dari: URL: HYPERLINK http://www.reactgroup.org.

4. Peraturan Menteri Kesehatan (Permenkes) Nomor 2406/MENKES/PER/XII/2011. Pedoman umum penggunaan antibiotika.

5. Kumala S, Dimas AM, Pasanema, Mardiastuti. Pola resistensi antibiotik terhadap isolat bakteri sputum penderita tersangka infeksi saluran nafas bawah. 2010 (diunduh 10 Desember 2013). Tersedia dari: URL: HYPERLINK http://jfi.iregway.com/index.php/jurnal/article

\section{KESIMPULAN}

Hasil penelitian ini menyimpulkan bahwa 